\title{
Perspektywy rozwoju energii odnawialnej w Polsce
}

Emilia Łysik

Studentka, Uniwersytet Łódzki, Wydział Ekonomiczno-Socjologiczny, Katedra Gospodarki Światowej i Integracji Europejskiej

\section{Wstęp}

W niniejszej pracy podjęto próbę zaprezentowania w sposób teoretyczny i praktyczny odnawialnych źródeł energii w Polsce. Ukazane zostały instrumenty wsparcia zielonej energii oraz stan już zainstalowanych sieci energii odnawialnej. Praca przedstawia korzyści i koszty wynikające $\mathrm{z}$ energii odnawialnej. Jej istotą jest pokazanie dalszych szans rozwoju energii odnawialnej w perspektywie 2030 .

\section{Teoretyczne ujęcie odnawialnych źródeł energii}

Większość technologii wykorzystywanych do przetwarzania energii powoduje wzrost zanieczyszczenia środowiska, które objawia się w postaci kwaśnych deszczy czy efektu cieplarnianego. Najbardziej szkodliwe skutki dla środowiska wywołuje energia pozyskiwana z konwencjonalnych źródeł, wytwarzana z ropy naftowej i węgla. Wraz ze wzrostem świadomości ekologicznej podjęto działania mające na celu ograniczenie emisji dwutlenku węgla oraz eliminowanie start energii ${ }^{1}$.

W Polsce energia elektryczna wytwarzana jest głównie z paliw kopalnianych, do których zalicza się węgiel kamienny i węgiel brunatny. Niestety wykorzystywanie tych paliw wiąże się ze szkodliwym wpływem na środowisko oraz wzrostem cen, które są spowodowane ograniczeniem zapasów surowców energetycznych ${ }^{2}$.

\footnotetext{
1 G. Jastrzębska, Odnawialne źródła energii i pojazdy proekologiczne, Wydawnictwo Naukowo-Techniczne, Warszawa, 2007,s. 23-27.

2 Ibidem.
} 
Szybki postęp technologiczny i rozwój cywilizacji przyczyniły się do transformacji energetycznej, która umożliwia produkcję energii z ogólnie dostępnych, niekończących się i w pełni darmowych źródeł, takich jak: promieniowanie słoneczne, wiatr czy przepływ wody ${ }^{3}$.

Energię pochodzenia naturalnego nazywamy energią ze źródeł odnawialnych (OZE). Aby energię można było nazywać odnawialną musi pochodzić ona $\mathrm{z}$ naturalnych regularnych procesów przyrodniczych i niekopalnych źródeł energii, które są bardziej przyjazne dla środowiska ${ }^{4}$. Ulokowana w odnawialnych źródłach energii moc pozwala na dostarczenie większej ilości zasobów energii niż są one wykorzystywane. Energia z promieniowania słonecznego dostarcza 15 tysięcy razy więcej energii, niż ta, która jest pozyskiwana ze źródeł konwencjonalnych (węgiel, ropa) ${ }^{5}$.

W 2015 roku została przyjęta Ustawa o Odnawialnych Źródłach Energii, która określa zakres prowadzenia działalności w tym obszarze. Według ustawy do odnawialnych źródeł energii zalicza się:

- energię wiatru,

- energię promieniowania słonecznego,

- energię geotermalną,

- energię hydrotermalną,

- hydroenergię,

- energię fal, prądów i pływów morskich,

- energię otrzymywaną z biomasy, biogazu, biogazu rolniczego oraz z biopłynów.

Polska, jako członek Unii Europejskiej zobowiązała się do przestrzegania norm środowiskowym i tym samym do restrukturyzacji sektora energetycznego. W tym celu została przyjęta Polityka Energetyczna Polski do roku 2030, która została zatwierdzona w 2009 roku przez Radę Ministrów. Skupia się ona na poprawie efektywności energetycznej, rozwoju wykorzystania odnawialnych źródeł energii, szczególnie biopaliw oraz ograniczeniu oddziaływania energetyki na środowisko7.

Polityka ta zakłada rozwiązania, które wyjdą naprzeciw polskiej energetyce i zachęcą do dynamicznego rozwoju zielonej energii. Mechanizmami pobudzającymi rozwój odnawialnych źródeł są:

- mechanizmy podatkowe,

- wspieranie projektów OZE z funduszy ochrony środowiska i UE,

3 B. Maciejewska, D. Szwed, Demokracja energetyczna, Zielony Instytut, Warszawa, 2013, s. 5.

4 GUS, Energia ze źródeł odnawialnych w 2014 r., Warszawa, 2015.

5 G. Jastrzębska, Odnawialne źródła energii..., s. 18-20.

6 Ustawa z dnia 20 lutego 2015 r. o odnawialnych źródłach energii, s. 3.

7 Ministerstwo Gospodarki, Prognoza i zapotrzebowanie na paliwa i energię do roku 2030, www.mg.gov.pl/files/upload/8134/Prognoza\%20zapotrzebowania\%20na\%20paliwa\%20 ¡\%20energie-ost.pdf. [dostęp online: 18.05.2016]. 
- zwolnienie z akcyzy energii elektrycznej z OZE,

- świadectwa pochodzenia oraz inne systemy wsparcia przedsiębiorstwa przy produkcji OZE 8 .

Energia wytwarzana z OZE daje różne możliwości energetyczne, ze względu na technologie można wyodrębnić cztery nośniki energii, co przedstawia poniższa tabela 1.

\begin{tabular}{|l|l|}
\hline \multicolumn{1}{|c|}{ Rodzaj wytwarzanej energii } & \multicolumn{1}{c|}{ Źródło energii } \\
\hline Energia elektryczna & $\begin{array}{l}\text { - Elektrownie wiatrowe, } \\
\text { - Elektrownie wodne, } \\
\text { - Ogniwa fotowoltaiczne }\end{array}$ \\
\hline Energia ciepła i energia elektryczna & $\begin{array}{l}\text { - Instalacje do wykorzystywania biogazu z organicznych } \\
\text { odpadów rolniczych i przemysłowych, odpadów } \\
\text { komunalnych i osadów oczyszczalni ścieków, biopaliw } \\
\text { stałych }\end{array}$ \\
\hline Energia ciepła & $\begin{array}{l}\text { - Ciepłownie geotermalne, } \\
\text { - Kolektory słoneczne }\end{array}$ \\
\hline Energia napędzająca pojazdy mechaniczne & $\begin{array}{l}\text { - Biopaliwa płynne, } \\
\text { - Biopaliwa ciekłe, } \\
\text { - Biogaz }\end{array}$ \\
\hline
\end{tabular}

Tabela 1. Rodzaje energii wytwarzanej i jej źródła.

Źródło: opracowanie własne na podstawie M. Ligus, Efektywność inwestycji w odnawialne źródła energii, CeDeWu.PL, Warszawa, 2010, s. 118-119.

\section{Mechanizmy i instrumenty wspierające inwestycję w energię odnawialną}

Kluczową rolę w rozwoju odnawialnych źródeł energii przypisuje się instytucjom i programom finansowania zielonych przedsięwzięć (Tabela 2.). Są one motorem napędzającym produkcję czystej energii. Instrumenty polityki strukturalnej i dotacje z budżetu ogólnego UE charakteryzują się tym, że są bezzwrotne. W zależności od poziomu projektu lub technologii dopasowywany jest mechanizm finansowania. W ramach programów ramowych realizowane będą na przykład działania badawczo-rozwojowe. Natomiast wsparcie poprzez instrumenty polityki regionalnej i programy specjalne będą miały projekty pilotażowe, technologie komercjalizacji i projekty wdrażania ${ }^{9}$.

8 Ramy prawne projektów związanych z odnawialnymi źródłami energii w Polsce, www.paiz. gov.pl/prawo/odnawialne_zrodla_energii [dostęp online: 18.05.2016].

9 K. Pająk, J. Mazurkiewicz, Mechanizmy wspierania rozwoju energetyki odnawialnej, www.ue. katowice.pl/fileadmin/_migrated/content_uploads/ 23_K.Pajak_J.Mazurkiewicz_Mechanizmy_wspierania_rozwoju...pdf [dostęp online: 19.05.2016]. 


\begin{tabular}{|l|l|}
\hline \multicolumn{1}{|c|}{ Instytucja } & \multicolumn{1}{c|}{ Rodzaj finansowania } \\
\hline Komisja Europejska & $\begin{array}{l}\text { Programy ramowe } \\
\text { Program na Rzecz Konkurencyjności i Innowacyjności: } \\
\text { Wsparcie dla MiŚP, Program Inteligent Energy - Europe } \\
\text { Polityka regionalna: EFRR, FS }\end{array}$ \\
\hline Europejski Bank Inwestycyjny & $\begin{array}{l}\text { Pożyczki } \\
\text { Linie kredytowe }\end{array}$ \\
\hline Europejski Bank Odbudowy i Rozwoju & SIĘ \\
\hline
\end{tabular}

Tabela 2. Instytucje i instrumenty wsparcia OZE. Źródło: opracowanie własne na podstawie Ecofys, Financing Renewable Energy in the European Energy Market, raport przygotowany dla Komisji Europejskiej, styczeń, 2011, s. 57.

Do pierwszej grupy instrumentów należy Ramowy Program na Rzecz Konkurencyjności i Innowacyjności, którego środki są przeznaczane na pomoc małym i średnim przedsiębiorstwom poprzez dofinansowanie kapitału i system poręczeń w początkowych fazach rozwoju. W drugiej grupie instrumentów jest Program Inteligentna Energia dla Europy, który wspiera działania edukacyjne i promocyjne. Instrumentami są także ELENA i ALTENER, które dostarczają środki na opracowanie programów inwestycyjnych w celu zwiększenia efektywności energetycznej i budowaniu OZE. Najważniejszym źródłem finansowania są środki przeznaczane na inwestycje energetyczne z Europejskiego Banku Inwestycyjnego (EBI). Oferuje on pożyczki dla banków, publicznych instytucji i prywatnych przedsiębiorców oraz linie kredytowe skierowane do instytucji finansowych ${ }^{10}$.

Za podstawę funkcjonowania zróżnicowanych systemów wsparcia energii z odnawialnych źródeł wyróżnia się dwa mechanizmy (Tabela 3.). Pierwszym mechanizmem jest system kształtowania cen, który odgórnie ustala ceny energii z OZE. Drugim jest system kształtowania ilości wytworzonej energii, który zapewnia zakup danej ilości energii z OZE i ukształtowanie ceny energii według mechanizmu rynkowego. Gwarancja zakupu jest potwierdzona poprzez system certyfikatów lub system przetargowy ${ }^{11}$.

10 K. Pająk, J. Mazurkiewicz, Mechanizmy wspierania rozwoju...

11 Ibidem. 


\begin{tabular}{|l|l|l|l|l|l|}
\hline \multicolumn{2}{|c|}{ Instrumenty wsparcia OZE } \\
\hline \multicolumn{2}{|l|}{ System kształtowania cen } & $\begin{array}{l}\text { System kształtowania wytwo- } \\
\text { rzonej energii }\end{array}$ & Zielone certy- \\
$\begin{array}{l}\text { Ceny gwaran- } \\
\text { towane }\end{array}$ & $\begin{array}{l}\text { Dopłaty gwa- } \\
\text { rantowane } \\
\text { fikaty }\end{array}$ \\
\hline
\end{tabular}

Tabela 3. Mechanizmy wsparcia OZE.

Źródło: opracowanie własne na podstawie K. Pająk, J. Mazurkiewicz, Mechanizmy wspierania rozwoju energetyki odnawialnej, www.ue.katowice.pl/fileadmin/_migrated/content_uploads/23 _K.Pajak_J.Mazurkiewicz_Mechanizmy_wspierania_rozwoju...pdf [dostęp online: 19.05.2016].

$\mathrm{Z}$ dniem 1 lipca 2016 roku planowane jest wprowadzenie systemu aukcyjnego, regulującego zakup energii elektrycznej z instalacji OZE oraz mechanizmy wspierające energie elektryczną w mikroinstalacjach o mocy nie większej niż 10kW. System aukcyjny ma zastąpić obecny system certyfikatów (zielone certyfikaty) i będzie polegał na zamówieniu przez rząd ilości energii odnawialnej, a wytwórcy poprzez aukcję będą mieli możliwość złożenia oferty o najkorzystniejszych warunkach. System certyfikatów w przeciwieństwie do systemu aukcyjnego nie ma ustalonego poziomu przychodów ze sprzedaży certyfikatów, co ogranicza ryzyko inwestycyjne ${ }^{12}$. Mechanizm aukcyjny wyklucza wsparcie dla instalacji hydroenergetycznych powyżej 5MW, instalacji OZE o mocy elektrycznej powyżej 50MW oraz instalacji współspalania ${ }^{13}$.

Powyższe instrumenty wsparcia dotyczyły energii wytwarzanej przez makroinstalacje i nie tylko, które są przeznaczone na sprzedaż. W 2015 roku Narodowy Fundusz Ochrony Środowiska i Gospodarki Wodnej (NFOŚiGW) stworzył program Prosument, który wspiera odnawialną energię wytwarzaną na własne potrzeby oraz sprzedaż nadwyżek energii do sieci elektroenergetycznej. Dofinansowanie jest przeznaczone na kupno i montaż mikroinstalacji OZE. Program ma na celu ograniczenie emisji $\mathrm{CO}_{2}$, zwiększenie udziału odnawialnych źródeł energii wykorzystywanych do energii cieplnej i elektrycznej, wzrost zatrudnienia oraz wzrost świadomości ekologicznej ${ }^{14}$.

12 System aukcyjny od 1 lipca 2016 roku, www.magazynbiomasa.pl/uruchomienie-systemu-aukcyjnego-prawdopodobnie-odroczone/ [dostęp online: 19.05.2016].

13 Projekt ustawy o odnawialnych źródłach energii, www.codozasady.pl/projekt-ustawy-o-odnawialnych-zrodlach-energii-oze/ [dostęp online: 19.05.2016].

14 Program priorytetowy, Wspieranie rozproszonych, odnawialnych źródeł energii. 


\section{Odnawialne źródła energii w Polsce}

Największy potencjał Polskiej gospodarki jest w sektorach energii wiatrowej i energii z biomasy. Najczęściej wykorzystywanym źródłem energii elektrycznej do tej pory był wiatr. Energia z wiatru jest produkowana w ilościach masowych jak również na małą skalę przy wykorzystaniu małych wiatraków przydomowych. Obecnie Polska zajmuje drugie miejsce w Europie pod względem nowych instalacji elektrowni wiatrowych ${ }^{15}$.

Nadchodzące zmiany przepisów w roku 2016 dotyczące wsparcia farm wiatrowych spowodowały uruchomienie dużej ilości wiatraków do końca roku 2015. Według danych Urzędu Regulacji Energetyki w 2015 roku zainstalowano famy wiatrowe o łącznej mocy 4582,036 MV (wykres 1.). Obawy inwestorów spowodowały szybki przyrost elektrowni wiatrowych, które pobiły rekord mocy i przyczynił się do wyprzedzenia założeń rządowych, co najmniej na trzy lata ${ }^{16}$.

Jak wynika z Wykresu 1. w roku 2015 odnotowano przyrost o wysokości $1280 \mathrm{MV}$. Widać także, że z roku na rok wzrost mocy farm wiatrowych był większy. Istotny wpływ na tak duży wzrost elektrowni wiatrowych miały przepisy prawne oraz instrumenty wsparcia. W tym roku $\mathrm{z}$ dniem 1 lipca przepisy dotyczące finansowania elektrowni wiatrowych mają ulec zmianie na ich niekorzyść, co spowoduje stagnację ich rozwoju. Dotyczyć one będą w dużej mierze lokalizacji farm od miejsc zabudowy ${ }^{17}$.

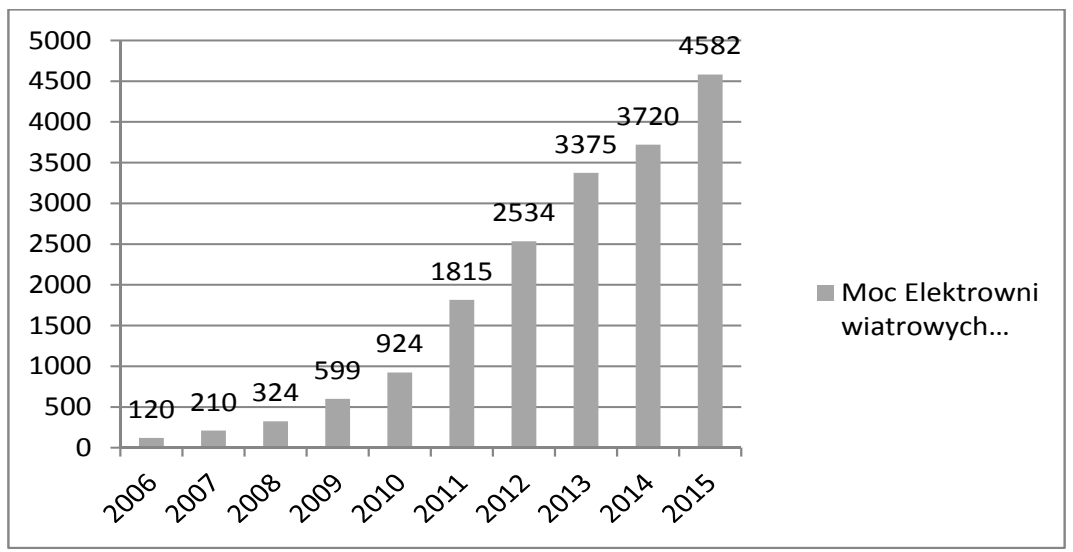

Wykres 1. Moc Elektrowni wiatrowych w Polsce w latach 2006-2015

Źródło: B. Derski, W Polsce już 5005 MV w farmach wiatrowych, www.wysokienapiecie.pl/oze/ 1214-w-polsce-juz-5000-mw-w-farmach-wiatrowych [dostęp online: 19.05.2016].

15 Odnawialne źródła energii, www.oze.pl/animacja-oze [dostęp online: 19.05.2016].

16 B. Derski, W Polsce...

17 G. Barzyk, Zmiany dotkną również mniejszych wiatraków, CZysta energia", nr 4, 2016, s. 29. 
Następnym źródłem energii pod względem ilości zainstalowanych mocy w Polsce jest biomasa (Tabela 4.). Na biomasę składają się wszystkie substancje pochodzenia roślinnego i zwierzęcego, które uległy biodegradacji, jak również produkty i odpady. Wycenia się, że zasoby biomasy, jako surowca energetycznego jest 25-30 mln ton rocznie, co jest równoważne 15-20 mln ton węgla kamiennego. Największym dostawcą biomasy w Polsce jest rolnictwo. Coraz częściej wykorzystuje się biomasę w energetyce cieplnej, jako paliwa ekologiczne $e^{18}$.

Przykładem inwestycji na skalę krajową jest projekt firmy Envirotech z Poznania, która ma na celu modernizację dostarczania ciepła dla miasta Złoczew w województwie łódzkim. Celem tego przedsięwzięcia jest ograniczenie substancji szkodliwych poprzez wykorzystanie energii z OZE. Starą ciepłownie węgla zastąpiono ekologiczną, wykorzystując biomasę i energie słoneczną ${ }^{19}$.

Innym przykładem inwestycji w odnawialne źródła energii w Polsce był Podlasie Solar Park, realizowany w 2013-2015 roku. W ramach projektu powstały cztery elektrownie słoneczne o łącznej mocy 3,82 MV $\mathrm{w}$ województwie podlaskim. Dzięki temu projektowi powstały nowe miejsca pracy, zaangażowano lokalne przedsiębiorstwa w realizację projektu, jak i mieszkańców ${ }^{20}$.

\begin{tabular}{|l|c|c|}
\hline \multicolumn{1}{|c|}{ Rodzaj energii } & llość & Moc MV \\
\hline Biogaz & 278 & 212.497 \\
\hline PV & 268 & 71.030 \\
\hline Woda & 752 & 981.799 \\
\hline Biomasa & 38 & 1122.670 \\
\hline Wiatr & 1039 & 4582.036 \\
\hline
\end{tabular}

Tabela 4. Stan instalacji OZE w Polsce i ich moc w roku 2015.

Źrodło: opracowanie własne na podstawie: www.ure.gov.pl/uremapoze/mapa.html [dostęp online: 19.05.2016].

Ilość zainstalowanych mocy i poszczególnych rodzajów odnawialnych źródeł energii w roku 2015 przedstawia tabela Można zauważyć, że na pierwszym miejscu są farmy wiatrowe, następnie energia pozyskiwana $z$ biomasy. Kolejnym źródłem energii są elektrownie wodne. Do najwięk-

18 D. Suszanowicz, Energia ze źródeł odnawialnych, Wydawnictwo i Drukarnia Świętego Krzyża w Opolu, 2015, s. 156-159.

19 T. Skibiński, OZE w systemie zaopatrzenia w ciepło ,„Czysta energia”, nr 2, 2015, s. 34-37.

20 T. Sęk, Cztery w jednym = Podlasie Solar Park ," Czysta energia”, nr 4, 2016, s. 37-39. 
szych hydroelektrowni w Polsce zalicza się elektrownie w Żarnowcu, Porąbka Żar, Solina, Włocławek i Żydowo. Coraz więcej inwestycji będzie kierowane na rozwój biogazowni, jak również kolektorów słonecznych.

\section{Korzyści i koszty energii odnawialnej}

Odnawialne źródła energii przyczyniają się do zmniejszenia emisji gazów cieplarnianych oraz współtowarzyszących im zanieczyszczeń, do których należą: dwutlenek siarki, pyły i tlenek azotu. Do przyjaznych dla środowiska źródeł energii zaliczana jest fotowoltaika, energia wiatrowa i wodna. Natomiast spalanie biomasy jest mniej korzystne, ze względu na emitowanie zanieczyszczeń. Oprócz pozytywnych aspektów środowiskowych odnawialne źródła energii mają korzystny wpływ na całą gospodarkę, a szczególnie na obszarach wiejskich. Pozwala to na generowanie oszczędności w gospodarstwach rolnych. Korzyścią z instalacji OZE pozwoli na zmniejszenie uzależnienia od dostaw energii z Rosji ${ }^{21}$.

Istnieje wiele powodów, dla których odnawialne źródłach energii stanowią kluczową rolę w rozwoju gospodarczym kraju. Pierwszym z nich jest ogólna dostępność do zasobu i jego bezgraniczność. Drugim ważnym argumentem szczególnie dla środowiska jest mniejsze ingerowanie w przyrodę niż tradycyjne źródła energii. Trzecim czynnikiem przemawiającym za odnawialnymi źródłami energii jest ograniczenie emisji zanieczyszczeń do atmosfery. Czwartym powodem wdrażania OZE jest niezależność energetyczna państw ${ }^{22}$.

Inwestycje w odnawialne źródła energii oraz korzystanie z wytworzonej energii niesie wiele korzyści dla społeczności lokalnych, jak i osób indywidualnych. Do zalet zalicza się uaktywnienie przedsiębiorczości i aktywizacja terenów wiejskich, między innymi wykorzystanie terenów, które leżą odłogiem lub są wyłączone z produkcji rolniczej. Poprzez realizację projektów OZE powstają nowe miejsca pracy, poprawia się koniunktura gospodarcza, jak również poprawia się bilans handlowy gminy wykorzystującej OZE. Instalacja energii odnawialnej pozwala na obniżenie kosztów ogrzewania budynków, dodatkowo jest możliwość uzyskania na nią wsparcia finansowego poprzez środki z UE. Kluczowe jest działanie proekologiczne, które wpływa na ochronę i poprawę środowiska ${ }^{23}$.

21 J. Golonko, Energia odnawialna: korzyść z OZE nie tylko dla środowiska, ale i naszych portfeli, www.polskieradio.pl/42/3167/Artykul/1119367,Energia-odnawialna-korzysci-z-OZE-nie-tylko-dla-srodowiska-ale-i-naszych-portfeli [dostęp online: 19.05.2016].

22 K. Łapiński, Odnawialne źródła energii, www.praze.pl/UserFiles/File/Pakiety/7.6/Prezentacja\%20dla\%20szkol.pdf [dostęp online: 19.05.2016].

23 Odnawialne źródła energii, www.zielonetechnologie.pl/html/pubonline/downloads/BIO-WAT.pdf [dostęp online: 20.05.2016]. 
Oprócz korzyści odnawialne źródła wiążą się z kosztami, które można podzielić na finansowe i środowiskowe. Do kosztów finansowych zalicza się nakłady związane z finansowaniem zielonych inwestycji. Niestety technologie wykorzystywane do pozyskiwania energii odnawialnych są o wiele droższe niż technologie konwencjonalne.

\section{Szanse rozwoju odnawialnych źródeł energii w Polsce}

Odnawialne źródła energii miały zapewnić większą efektywność wykorzystania energii, miały być tańsze i stabilniejsze. Sądząc po doświadczeniach takich krajów jak Holandia, Wielka Brytania, czy Włochy system aukcyjny nie zdał egzaminu. Celem było zwiększenie produkcji czystej energii, zmniejszając tym koszty wsparcia. Pierwsze aukcje we Włoszech i Holandii wygrały projekty farm wiatrowych. Przykładowo aukcję we Włoszech wygrał projekt farmy wiatrowej o łącznej mocy 1300MV, natomiast w ciągu roku powstało ich tylko 400MV nowych farm. Realizacja tego projektu nie osiągnęła nawet $40 \%$. Dlatego też podobnych skutków systemu aukcyjnego możemy się spodziewać w Polsce. Jedynym plusem jest to, że nie będzie można złożyć oferty z ceną, która nie zrealizuje projektu. Zabezpieczenie projektu polegać będzie na gwarancji bankowej w wysokości 30 tys. zł za $1 \mathrm{MV}$ instalacji. Niestety system aukcyjny nie zakłada minimalnej stawki oferowanej ceny. Może to skutkować wycofaniem się inwestorów z realizacji projektu kilka tygodni tuż po wygranej aukcji, tak jak to było w Wielkiej Brytanii. Prognoza skutków zmian w ustawie OZE zakłada, że projekty wygrane będą zrealizowane w ciągu dwóch lat, mimo czteroletniego terminu budowy instalacji. Patrząc na doświadczenia krajów, w których system aukcyjny istnieje już kilka lat widać, że projekty nie są realizowane w krótkim czasie, wręcz powstaje ich rynek wtórny ${ }^{24}$.

Uwzględniając zagrożenia wynikające $\mathrm{z}$ systemu aukcyjnego, można wnioskować, że będzie to duże wyzwanie dla Polski. Wytwarzanie energii ze źródeł odnawialnych ma ogromny potencjał, ale czy zostanie on w pełni wykorzystany? Wizja stabilnych dochodów może budzić zachętę dla inwestorów, jak również ogromne ryzyko popełnienia tych samych błędów, których powinniśmy unikać ucząc się na błędach innych krajów ${ }^{25}$.

Według Bloomberga w 2040 roku rynek energetyczny będzie w 56\% miał udział z zero emisyjnych źródeł energii. Twierdzi on również, że

\footnotetext{
24 A. Sekściński, Aukcje OZE - wyciagnąć wnioski z doświadczeń Europy , "Czysta energia”, nr 1, 2016, s. 23.

25 A. Sekściński, Aukcje OZE - wyciagnąć wnioski..., s. 23.
} 
w ciągu 25 lat 66\% funduszy przeznaczone będzie na instalacje OZE oraz zakłada przyrost mocy o $9786 \mathrm{GW}$, co będzie stanowiło prawie $60 \%$ energii z OZE. Koszty instalacji farm wiatrowych spadną o $32 \%$, a instalacja ogniw fotowoltaicznych o 48\%. Nastąpi gwałtowny rozwój małych i średnich instalacji pochodzących od prosumenta. Największym konkurentem dla pozostałych źródeł energii odnawialnej będzie energia słoneczna, która przekroczy 3400GW. Należy też brać pod uwagę, że wszystkie prognozy, mogą ulec zmianie ze względu na postęp nauki i techniki ${ }^{26}$.

Dalsze losy rozwoju OZE w Polsce w dużej mierze są zależne od rządu i podejmowanych przez niego decyzji. Odnawialne źródła energii są traktowane przez rządzących, jako coś zupełnie niepotrzebnego, co może zaszkodzić obecnemu systemowi energetycznemu i co wymaga dodatkowego wsparcia finansowego. Przygotowanie ustawy o OZE trwało niemal cztery, została ona podpisana 20 lutego 2015, natomiast jej nowelizacja została zatwierdzona 30 grudnia 2015 roku i jest odroczona do 1 lipca 2016 roku. Jest to spowodowane zmianami w czwartym rozdziale, które dotyczą mechanizmów i instrumentów wsparcia. Z projektu wynika, że zmiany nie będą korzystne i nie będzie on skierowany na wspieranie energetyki wiatrowej. Zmienione zostaną zasady dotyczące biogazowni, między innymi przywrócenie współspalania ${ }^{27}$.

\section{Podsumowanie}

Polityka klimatyczno-energetyczna jest dużym wyzwaniem dla krajów członkowskich Unii Europejskiej i stawia w dużej mierze na wymogi dotyczące redukcji emisji dwutlenku węgla. Dla Polski są to duże koszty obciążające gospodarkę, a $z$ drugiej strony ma to negatywny wpływ na grupy energetyczne opierające się na węglu. Marnotrawstwo i zmniejszanie się zasobów surowców kopalnianych przyczyniły się do zmian w systemach energetycznych. Energia ze źródeł odnawialnych ma za zadanie zapewnić efektywność energetyczną, przyczynić się do udziału klientów w oszczędzaniu poprzez budowanie małych przydomowych instalacji oraz pomóc w zmniejszeniu nadmiernych emisji gazów cieplarnianych. Odnawialne źródła energii są wykorzystywane na szeroką skalę a wraz z nimi systemy technologii informacyjnej (IT). Obok elektrowni systemowych funkcjonują wielkoskalowe odnawialne źródła energii, takie jak farmy wiatrowe i słoneczne, źródła konwencjonalne i energia rozproszona. Istnieją także prosumenci, którzy produkują energię na własne potrzeby, a jej nadmiar odsprzedają do sieci elektroenergetycznej.

26 "Czysta energia”, nr 9, 2015.

27 J. Starościk, Dlaczego o rozwój OZE ciagle trzeba walczyć? ,"Czysta energia”, nr 3, 2016, s. 48. 


\title{
Bibliografia
}

\section{Literatura książkowa}

Jastrzębska G., Odnawialne źródła energii i po- Maciejewska B., Szwed D., Demokracja energejazdy proekologiczne, Wydawnictwo Naukowo-Techniczne, Warszawa, 2007.

Ligus M., Efektywność inwestycji w odnawialne źródła energii, CeDeWu.PL, Warszawa, tyczna, Zielony Instytut, Warszawa, 2013. 2010.

Suszanowicz D., Energia ze źródełodnawialnych, Wydawnictwo i Drukarnia Świętego Krzyża w Opolu, Opole, 2015.

\section{Dokumenty}

Główny Urząd Statystyczny Energia ze źródeł Ramy prawne projektów związanych z odnaodnawialnych w 2014, Warszawa, 2015. wialnymi źródłami energii w Polsce.

Ustawa z dnia 20 lutego 2015 r. o odnawialnych Ecofys, Financing Renewable Energy in the Euźródłach energii.

Ministerstwo Gospodarki, Prognoza i zapotrzeropean Energy Market, raport przygotowany dla Komisji Europejskiej, styczeń, 2011.

\section{Czasopisma}

Czysta energia, $\mathrm{nr} 2,2015$.

Czysta energia, nr 9, 2015.

Czysta energia, nr 1, 2016.

Czysta energia, nr 3, 2016.

Czysta energia, nr 4, 2016.

\section{Strony internetowe}

\author{
www.ue.katowice.pl \\ www.magazynbiomasa.pl \\ www.codozasady.pl \\ www.oze.pl \\ www.wysokienapiecie.pl \\ www.ure.gov.pl \\ www.polskieradio.pl \\ www.praze.pl \\ www.zielonetechnologie.pl
}

